\title{
Survey and zoning of nitrate-contaminated groundwater in Iran
}

\author{
Abolghasem Alighardashi*, Mohammad Javad Mehrani, \\ Department of Civil, Water and Environmental Engineering, Shahid Beheshti University, Tehran, Iran
}

\author{
Received 03 Jul 2016, \\ Revised 25 May 2017, \\ Accepted 29 May 2017 \\ Keywords \\ $\checkmark$ Groundwater; \\ $\checkmark$ Nitrate; \\ $\checkmark$ Zoning; \\ $\checkmark$ Iran; \\ $\checkmark$ GeneticAlgorithm; \\ AbolghasemAlighardashi \\ a_ghardashi@sbu.ac.ir \\ $\mathbf{+ 9 8 2 1 7 3 9 3 2 4 6 7}$
}

\begin{abstract}
Groundwater quality management is important in arid and semi-arid regions, as in Iran. Nitrate $\left(\mathrm{NO}_{3}{ }^{-}\right)$is a common anion that contaminates groundwater. The present study determined the nitrate concentrations of aquifers in Iran. Data derived from studies in which the nitrate concentration had minimal spatial error at different periods were used for analysis. This included a total number of 2353 nitrate samples taken from wells located in all area of Iran. These were extracted from 82 articles and covered all of provinces. Furthermore, in every region, the average and maximum nitrate concentration were identified and kriging interpolation technique was used to obtain the spatial distribution of groundwater quality parameters by Arc view GIS 10.2 software. The results showed that the nitrate levels in samples from some regions were above the maximum standard level. Nitrate contamination in some regions had increased over the last 10 years. Genetic algorithms were applied to determine the relationship between average nitrate concentration and population density, consumption of drinking water and agricultural water use. The results show that water use in agricultural areas and the subsequent consumption of fertilizer are the main source of groundwater contamination with nitrate in Iran.
\end{abstract}

\section{Introduction}

Environmental problems in arid and semi-arid regions such as Iran are becoming the focus of increasing international attention[1].Groundwater resource assessment, management and sustainability are of utmost importance in arid and semiarid regions where water is commonly of critical economic and social significance. Groundwater is the major source of water supplies for drinking and for the domestic, industrial, and agricultural sectors in Iran[2]. Many municipal water supplies are derived solely from groundwater. Polluted groundwater is less visible, but more difficult to clean up, than pollution in rivers and lakes[3]. Nitrate $\left(\mathrm{NO}_{3}{ }^{-}\right)$is present naturally in water body[4] and common anion that contaminates groundwater[5]. The state of groundwater pollution has become critical as the population and agricultural development have increased in Iran. Pollution assessment is an important factor in policymaking in any country[6]. Pollution assessment is a basis for initiating protective measures for important groundwater resources. Identifying nitrogen and processes affecting nitrate pollution is essential to improving water quality[7]. Groundwater is a major source of drinking water in Iran, supplies more than 50\% of public and accounts for almost all water supplies in rural households. Its contamination is one of the most serious problems in Iran[8]. Sources of nitrate pollution in groundwater can be either natural or human. Natural sources of pollution include nitrogen fixation in the soil (as a result of transformation of land) and influence the level of nitrates in the groundwater. Human sources include urban waste disposal, human waste through absorption wells, seepage from landfills, municipal wastewater, output of septic tanks and drain output caused by agricultural activity [9]. Natural transformation processes such as denitrification or nitrification also affect the nitrate concentration in groundwater. These are the most important sources of the increase in nitrates in the groundwater. Areas with a high level of groundwater and shallow aquifers are the first recipients of nitrate contamination [10]. Nitrate penetrates the soil and enters the groundwater. Because of its high water solubility and dispersion properties, it affects a wide span of area. Nitrates are mainly used as fertilizer in agriculture because of their high solubility and biodegradability [11]. For this reason, they are a major source of groundwater contamination. Nitrogen in different forms is a crucial input in agricultural production, but it puts environmental pressure on the groundwater, soil and air [12]. It is wellrecognized that groundwater is a valuable natural resource and should be protected from deterioration and chemical pollution; however, agricultural practices, demographic growth and economic development mean that 
the amount of nitrogen released to the subsurface from fertilizers, sewage and animal waste has increased over the last decade[13].The allowable limit of nitrates in water has been set at $50 \mathrm{mg} / \mathrm{lby}$ the Iranian National Institute of Standards [14], $50 \mathrm{mg} / \mathrm{l}$ by the World Health Organization [15] and $45 \mathrm{mg} / \mathrm{l}$ by the US Environmental Protection Agency [16].

Survey and zoning of groundwater contaminated by nitrates was beyond the scope of some studies. Bolgeret al.[17]zoned of underground water contaminated by nitrates in Australia using GIS to obtain the concentration of nitrates in different areas. They used reviews, books related to the issue, and local measures. Raheli-Namin et al. [18] as well zoned of groundwater-quality probability mapping and evaluated $\mathrm{Cl}, \mathrm{SO}_{4}, \mathrm{EC}$ and $\mathrm{NO}$, and selected the best geostatistical method for mapping groundwater quality in the Ghara-su Basin of Golestan Province, Iran. Wang et al. [19] used the nitrate concentrationsin616 irrigation wells to predict the nitrate concentrations in northern China using GIS. Another example of using GIS for the benefit of environmental problem-solving is a study by Nas and Berktay [20] in which groundwater contamination by nitrates in the city of Konya, Turkeywas simulated using data from139 wells in 1998 and 156 wells in 2001. The National Atmospheric Deposition Program in the USA has developed maps showing the spatial pattern of nitrates derived from selected sampling sites for 2002. They developed a contour map using the nitrate measurements at the specific sampling locations to create contours and isolines through interpolation of data points[21]. Furthermore Ben Aakame et al. [22] assessed the physicochemical quality (such as nitrate concentration) of well's water in the region of Northwest of Morocco, which is used in the supply of drinking water for a large population.In another research in this region, long-term assessment of surface and ground waters quality in Tensift region during the period of 2003 to 2012 was investigated[[23].

Official reports state that water contamination in Iran is caused by agricultural drainage water (87\%), sewage $(11 \%)$, and industrial wastewater (2\%).A significant percentage of contaminants in agricultural drainage water are from nutrients(fertilizers) and pesticides[24]. Although several studies on groundwater nitrate contamination have been carried out in Iran, none have investigated the overall nitrate concentrations in the groundwater resources. This research determined the range of contamination of groundwater resources with nitrates using GIS. It also presents a formula describing the relationship between nitrate concentration and the Iranian population density and water use by different sectors.

\section{Methods and Materials}

\subsection{Study area}

Iran is located in southwestern Asia at $24^{\circ}$ to $40^{\circ} \mathrm{N}$ latitude and $44^{\circ}$ to $64^{\circ} \mathrm{E}$ longitude (Figure 1). The climate is primarily very arid, arid or semi-arid, but some subtropical areas can be found along the Caspian coast [25].

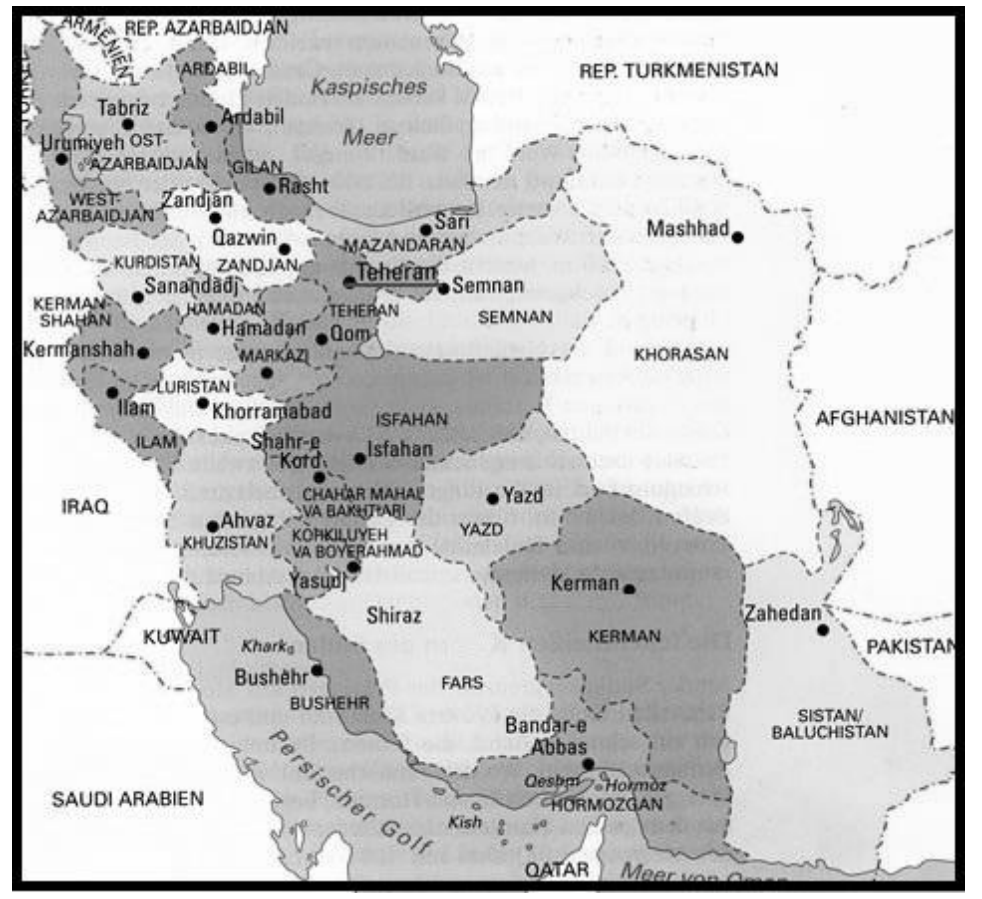

Figure 1: Study area 
Iran is the eighteenth largest country in the world with a total area of $1,648,195 \mathrm{~km}^{2}$. The capital and largest city is Tehran, which is located in north-central Iran. Other large cities are Mashhad, Karaj, Isfahan, and Tabriz. The total population is over 75 million, with over 12 million people living in Tehran alone[26].

\subsection{Data collection}

This research was carried out in two steps. The first was collection and entering the initial data (nitrate concentration) into the geographical information bank. The second was the preparation and analysis of maps. Data on the nitrate concentration in the groundwater were collected from papers published in international and national journals and those presented at conferences in the last ten years.

Google Scholar, Sciencedirect and Springer databases were searched using the keywords: nitrate concentration, nitrate pollution in groundwater, removal of nitrates, groundwater contaminated by nitrates, provincial capitals and major cities, especially in the important plains of Iran. Using initially, the total of 134 scientific articles survived; and then 82 regions were selected. The papers which had less credible or high error rates were removed from the database. National and official data such as population were collected from the Statistical Center of Iran [27].

\subsection{Technical analysis}

After collecting the data, the average and maximum concentration and their standard deviations (SD) were obtained and used to determine the average and maximum concentrations of nitrates in every region. The K-S test is the way to show whether the data is normal or not and this test was used in SPSS Statistics (ver. 19), for all regions. A total of 2353 wells in 82 regions of Iran were investigated. The regions were identified using Arc GIS software (ver. 10.2) and Google Earth. Genetic algorithms were applied using Genetic Algorithm (Gene X Pro Tools ver. 4.0) to discover the relationship between average nitrate concentration and population density, consumption of drinking water and agricultural water use.

\section{Results and Discussion}

\subsection{Analysis of data}

According to The K-S test shows in table 1, the average and maximum data both followed normal distributions. The regions and their UTM coordinates are listed in Table 2. The UTM coordinates are shown on the map of Iran in Figure 2. In analysis of average nitrate concentration in difference regions, only in 7 regions (about 8\%) have nitrate concentrations above the standard limit, however, when the maximum nitrate concentration was considered, this increases to 40 regions (49\%) (Figure 3).

Table 1: K-S Test

\begin{tabular}{|ll|r|r|}
\hline & & \multicolumn{1}{|c|}{ mean } & \multicolumn{1}{|c|}{$\max$} \\
\hline Normal Parameters ${ }^{\mathrm{a}, \mathrm{b}}$ & Mean & 82 & 82 \\
& Std. & 24.9641 & 58.5920 \\
& Deviation & 17.22212 & 50.00218 \\
& & & \\
Most Extreme Differences & Absolute & .137 & .156 \\
& Positive & .137 & .156 \\
& Negative & -.098 & -.156 \\
Kolmogorov-Smirnov Z & & 1.237 & 1.415 \\
Asymp. Sig. (2-tailed) & & 0.94 & .063 \\
\hline
\end{tabular}

a. Test distribution is Normal.

b. Calculated from data. 
Table 2: Region's location

\begin{tabular}{|c|c|c|c|c|c|c|c|c|c|}
\hline No & City or plain / Province (Code) & $\mathbf{X}$ & $\mathbf{Y}$ & Ref. & No & City or plain / Province (Code) & $\mathbf{X}$ & $\mathbf{Y}$ & Ref. \\
\hline 1 & Ardebil / Ardebil (1) & 260912.082 & 4236551.451 & [29] & 42 & Kerman / Kerman (18) & 507970.24 & 3350399.39 & [28] \\
\hline 2 & Tabriz / East Azarbayejan (2) & 613950.14 & 4213872.02 & [30] & 43 & Sirjan / Kerman (18) & 371354.07 & 3259417.5 & {$[28]$} \\
\hline 3 & Marand / East Azarbayejan (2) & 566627.06 & 4253457.23 & [32] & 44 & Songhor / Kermanshah(19) & 737651.41 & 3851587.4 & [31] \\
\hline 4 & Ahar / East Azarbayejan (2) & 680455.36 & 4262181.11 & [34] & 45 & Gorgan/ Golestan (20) & 271722.86 & 4080798.07 & [33] \\
\hline 5 & Bonab / East Azarbayejan(2) & 593450.97 & 4133165.73 & [36] & 46 & Gharasoo/ Golestan (20) & 236784.66 & 4079784.5 & [35] \\
\hline 6 & Maraghe/ East Azabayejan (2) & 556478.25 & 4135176.21 & [38] & 47 & Gilan plain / Gilan (21) & 375429.1 & 4127091.07 & [37] \\
\hline 7 & Khoy / West Azarbayejan (3) & 494708.5 & 4267245.92 & [30] & 48 & Talesh / Gilan (21) & 378541.2 & 4156347.2 & [39] \\
\hline 8 & Mahabad / West Azarbayejan (3) & 564389.93 & 4068795.35 & [41] & 49 & Shiraz / Fars (22) & 653481.7 & 3273896.39 & {$[40]$} \\
\hline 9 & Karaj / Alborz (4) & 494588.44 & 3966228.27 & {$[43]$} & $\mathbf{5 0}$ & Darab / Fars (22) & 261195.27 & 3183465.22 & {$[42]$} \\
\hline 10 & Hashtgerd / Alborz (4) & 471557.01 & 3979815.06 & [1] & 51 & Kamfirooz / Fars (22) & 614650.52 & 3355300.2 & [44] \\
\hline 11 & Arak / Markazi (5) & 379017.24 & 3773301.25 & {$[46]$} & 52 & Pasargad / Fars (22) & 709730.03 & 3343319.56 & [45] \\
\hline 12 & Koohroud / Markazi (5) & 418894.72 & 3893608.86 & [46] & 53 & Zarghan / Fars (22) & 623541.65 & 3254781.25 & [47] \\
\hline 13 & Amanabad / Markazi (5) & 412065.62 & 3742684.96 & [46] & 54 & Marvdasht / Fars (22) & 651245.85 & 3325478.21 & [47] \\
\hline 14 & Eilam / Eilam (6) & 631191.43 & 3722552.41 & {$[48]$} & 55 & Droudzan / Fars (22) & 703164.7 & 3112549.7 & [47] \\
\hline 15 & Esfahan / Isfahan (7) & 562919.76 & 3613244.75 & {$[50]$} & 56 & Lorestan / Lorestan (23) & 260915.25 & 3724910.93 & [49] \\
\hline 16 & Varzane / Isfahan (7) & 655146.6 & 3588329.97 & {$[52]$} & 57 & Romeshgan / Lorestan (23) & 274156.32 & 3687351.51 & [51] \\
\hline 17 & Shahreza / Isfahan(7) & 581470.63 & 3541670.94 & [54] & 58 & Sari / Mazandaran(24) & 684079 & 4047821.04 & [53] \\
\hline 18 & Kashan / Isfahan(7) & 537998.54 & 3761593.66 & [54] & 59 & Sari plain / Mazandaran(24) & 490707.1 & 4051471.91 & [55] \\
\hline 19 & west of Esfahan / Isfahan(7) & 523541.21 & 36125781.25 & [57] & 60 & Mazandaran plain / Mazandaran(24) & 495216.25 & 3945621.37 & [56] \\
\hline 20 & Ardestan / Isfahan(7) & 536571.25 & 36814125.63 & [59] & 61 & Nour / Mazandaran(24) & 492574.12 & 4025891.35 & [58] \\
\hline 21 & Borazjan / Boushehr $(8)$ & 521120.4 & 3237569.37 & {$[61]$} & 62 & Miandoroud / Mazandaran(24) & 5087153.2 & 4059862.3 & [60] \\
\hline 22 & Tehran / Tehran(9) & 538047.7 & 3949779.8 & {$[63][64]$} & 63 & Hamedan / Hamedan(25) & 272648.12 & 3853582.88 & [62] \\
\hline 23 & West Tehran/ Tehran(9) & 511375.63 & 3952995.71 & [43] & 64 & Toyserkan / Hamedan(25) & 266333.35 & 3826036.85 & [65] \\
\hline 24 & Shahriar / Tehran(9) & $\mathbf{5 0 1 8 5 5 . 2 7}$ & 3939058.98 & {$[67]$} & 65 & Sangestan / Hamedan(25) & 279955.5 & 3851708.93 & {$[66]$} \\
\hline 25 & Shahrekord / Charmahal(10) & 488270.71 & 3576883.95 & {$[69],[70]$} & 66 & Nahavand / Hamedan(25) & 257485.14 & 3786269.22 & [68] \\
\hline 26 & Lordegan / Charmahal(10) & 483807.85 & 3486157.05 & [72] & 67 & Alvand / Hamedan(25) & 259871.32 & 3725782.58 & [71] \\
\hline 27 & Mashhad / Khorasan Razavi(11) & 735332.82 & 4015988.88 & $\begin{array}{l}{[74],} \\
{[75]}\end{array}$ & 68 & Razan / Hamedan(25) & 263541.87 & 3845621.8 & [73] \\
\hline 28 & Khaf / Khorasan razavi(11) & 715489.25 & 3987415.24 & [77] & 69 & Yasooj / Kohkiloye(26) & 556311.81 & 3393008.77 & {$[76]$} \\
\hline 29 & Neyshabour/ KhoraanRazavi(11) & 694526.87 & 3712583.57 & [79] & 70 & Gachsaran / Kohkiloye(26) & 480122.8 & 3359486.21 & [78] \\
\hline 30 & Avan / Khouzestan(12) & 247048.48 & 3553848.8 & [47] & 71 & Bahabad / Yazd(27) & 407657.37 & 3526705.55 & [5] \\
\hline 31 & Eize / Khouzestan(12) & 393044.52 & 3521555.315 & [81] & 72 & Yazd / Yazd(27) & 267412.5 & 3447820.41 & {$[80]$} \\
\hline 32 & Dezfoul / Khouzestan(12) & 257538.09 & 3586028.12 & [83] & 73 & West Yazd / Yazd(27) & 250122.76 & 3532089.17 & [82] \\
\hline 33 & Zanjan / Zanjan(13) & 277226.42 & 4062758.25 & [85] & 74 & Zahedan / SistanBaluchestan(28) & 292925.47 & 3264769.46 & [84] \\
\hline 34 & Semnan / Semnan(14) & 715662.61 & 3939895.14 & [87] & 75 & Iranshahr / SistanBaluchestan(28) & 270478.71 & 3011080.64 & [86] \\
\hline 35 & Majn / Semnan(14) & 348983.9 & 3956992.62 & [89] & 76 & Minab / Hormozhan(29) & 507956.84 & 3002825.17 & {$[88]$} \\
\hline 36 & Shahrood / Semnan(14) & 328562.2 & 3974215.95 & [91] & 77 & Bandar lenge / Hormozhan(29) & 286205.8 & 2942563.03 & {$[90]$} \\
\hline 37 & Ghazvin / Gazvin(15) & 409959.76 & 4014889.32 & [93] & 78 & Bandar Abbas / Hormozgan(29) & 426575.04 & 3007437.1 & [92] \\
\hline 38 & Qom / Qom(16) & 488570.57 & 3833172.97 & [95] & 79 & Bojnord / north Khorasan(30) & 529077.91 & 4147491.8 & [94] \\
\hline 39 & Qorve / Kordestan(17) & 755308.41 & 3895266.6 & [96] & 80 & Bojnord plain/ north Khorasan(30) & 516894.09 & 4129908.06 & [94] \\
\hline 40 & Anar / Kerman(18) & 335150.09 & 3416578.71 & [98] & 81 & Birjand / south Khorasan(31) & 708372.52 & 3638565.7 & [97] \\
\hline 41 & Jiroft / Kerman(18) & 571973.9 & 3172441.37 & {$[100]$} & 82 & Birjand plain/ south Khorasan(31) & 712547.3 & 3538465.1 & [99] \\
\hline
\end{tabular}

\subsection{Graphical output}

GIS is a powerful and promising tool for problem-solving in environmental issues. Most of environmental problems have obvious spatial dimensions and spatially-distributed models can interact with GIS. Interpolation technique was used to obtain the spatial distribution of groundwater quality parameters for zoning nitrate concentrations across Iran because kriging is known as the best unbiased linear estimator. 


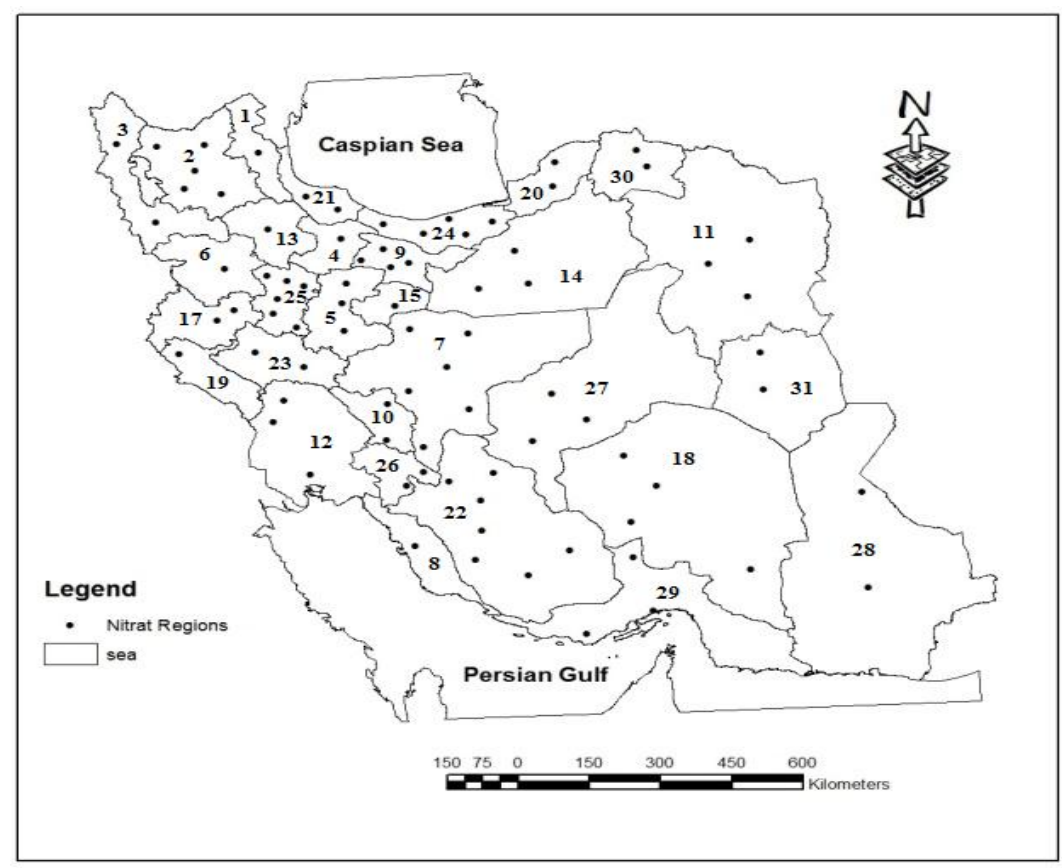

Figure 2: Location of 82 spatial regions.

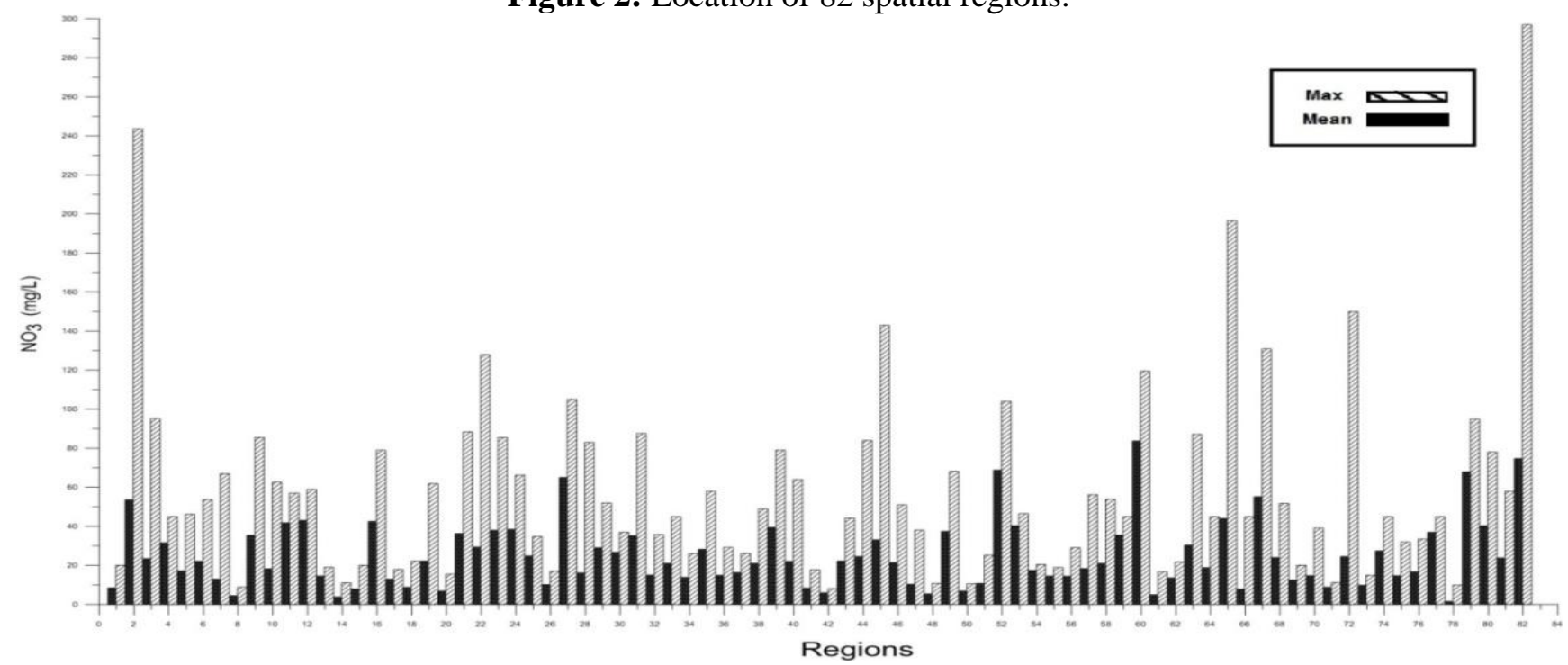

Figure 3: Mean and maximum concentrations of nitrate by region.

The output map for mean nitrate concentration (Figure $4 \mathrm{left}$ ) shows that high nitrate concentrations in groundwater were observed in the northeast (Khorasan province), northwest (Hamedan (25) and east Azerbaijan provinces (2)), southwest (Fars province (22)) and north (Mazandaran province (24)). The output map of maximum nitrate concentration shows that the highest nitrate concentrations were seen in the northeast (Golestan province (20)), northwest, north and center (Yazd province (27)).

The population density map (Figure 5) shows that the deserts located in the central plateau of Iran have the lowest population density. The highest population density is located in the north, northeast, northwest and west of Iran. Consequently, the highest nitrate concentrations were found in groundwater resource in the populated regions.

Official data on water consumption in agriculture and urban sectors was collected, analyzed and the patterns of water consumption were obtained using GIS kriging (Figure 6). A comparison of the agricultural water consumption and average nitrate concentration maps indicate that the regions contaminated by nitrates (average concentration of nitrate exceeds Iranian and international standards $\left(45 \mathrm{mg} / \mathrm{l} \mathrm{of} \mathrm{NO}_{3}^{-}\right)$) [14]. and the areas of high consumption of agricultural water coincide. Because a significant percentage of pesticide residue and chemical fertilizers remain in the agricultural drainage water, they ultimately enter the surface and groundwater sources. 

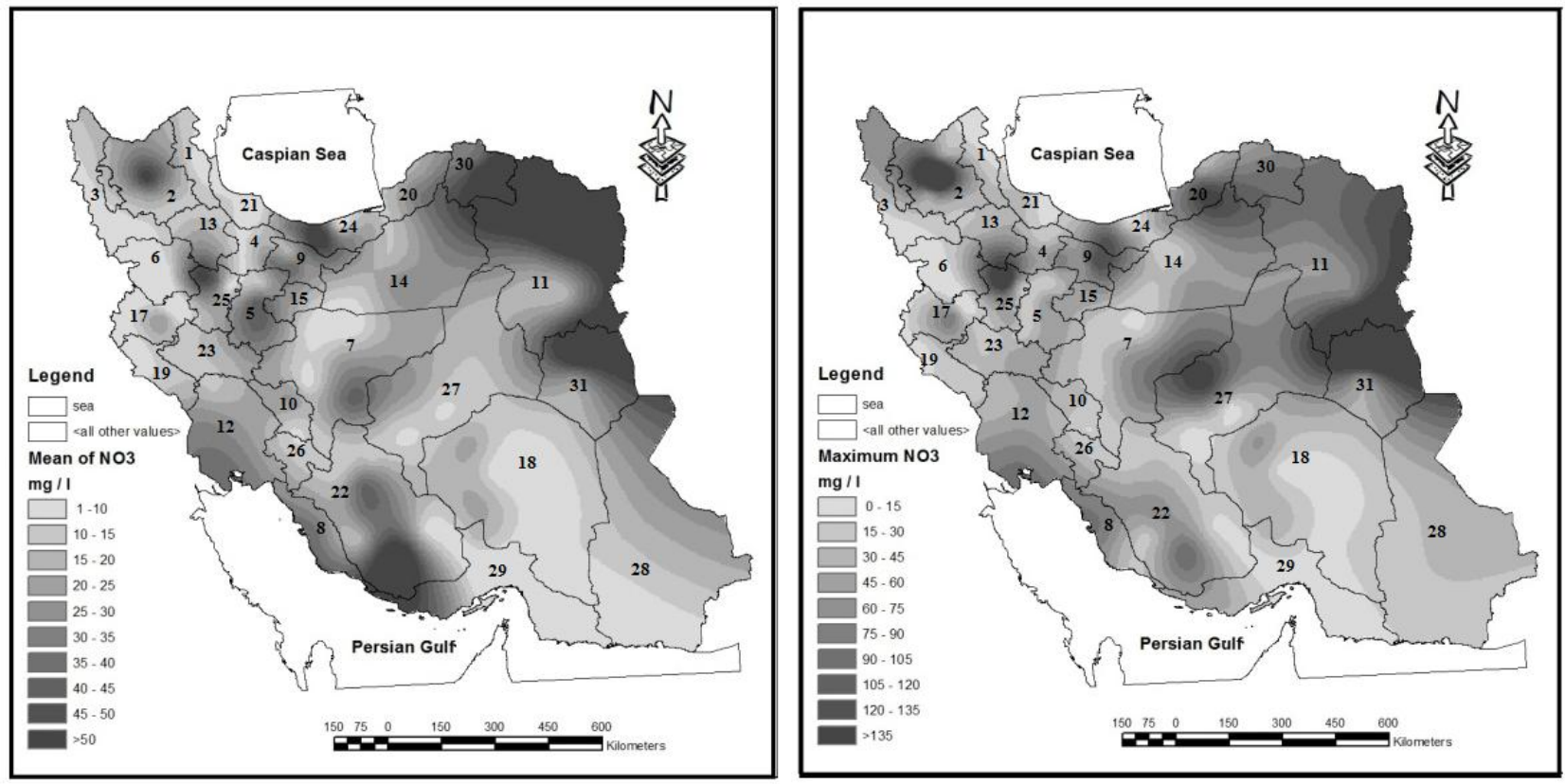

Figure 4: Spatial pattern of nitrates in Iran: (left) average; (right) maximum concentration.

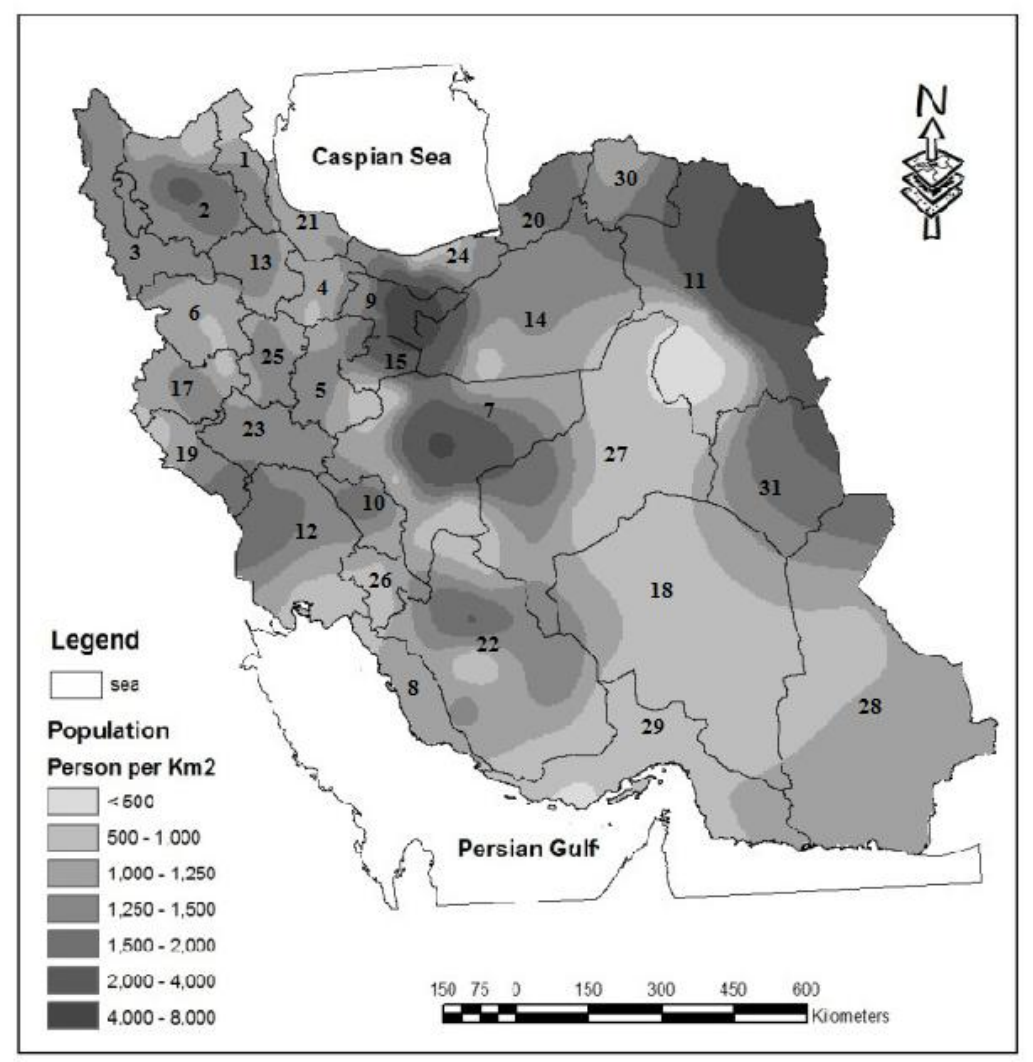

Figure 5: Population density of Iran.

The relationship between average nitrate concentration and population density, consumption of drinking water and agricultural water uses was obtained using Genetic Algorithm (Gene X Pro Tools ver. 4.0) as:

$$
N O_{3}=\left[\frac{\sin (-5.499 \times P \times D)}{\sin A^{3}}\right]+\left[\frac{2.024}{\sin D^{3}-\sin A \times 2.505}\right]+\left[\log \left(\left(A^{2}-2.603 \times D\right) \times(A-P)\right)^{2}\right](1)
$$


Where $\mathrm{A}$ is agricultural water use, $\mathrm{D}$ is drinking water, $\mathrm{P}$ is population and $\mathrm{NO}_{3}$ is the mean concentration of nitrates. The $\mathrm{R}^{2}$ was 0.76 and SD was 0.21 . Agricultural water use (A) had the maximum weight in the equation as was confirmed by trial and error in Excel software. This result depends on water use in the agricultural sector and consumption of fertilizer in Iran. The obtained results of formula and experimental data followed the linear correlation as shown in Figure 7.
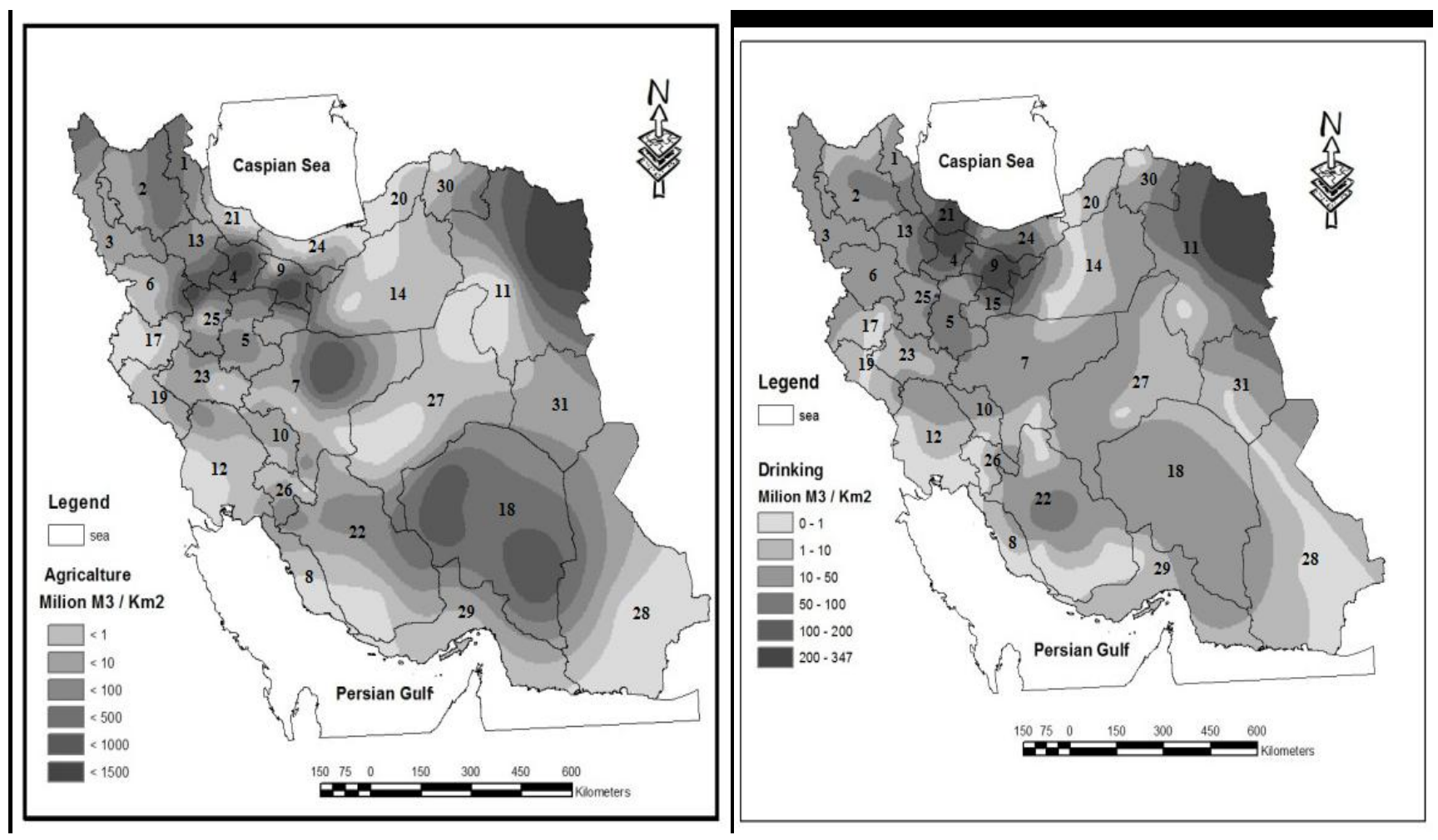

Figure 6: Zoning of water consumption: (left) agricultural water; (right) drinking water.

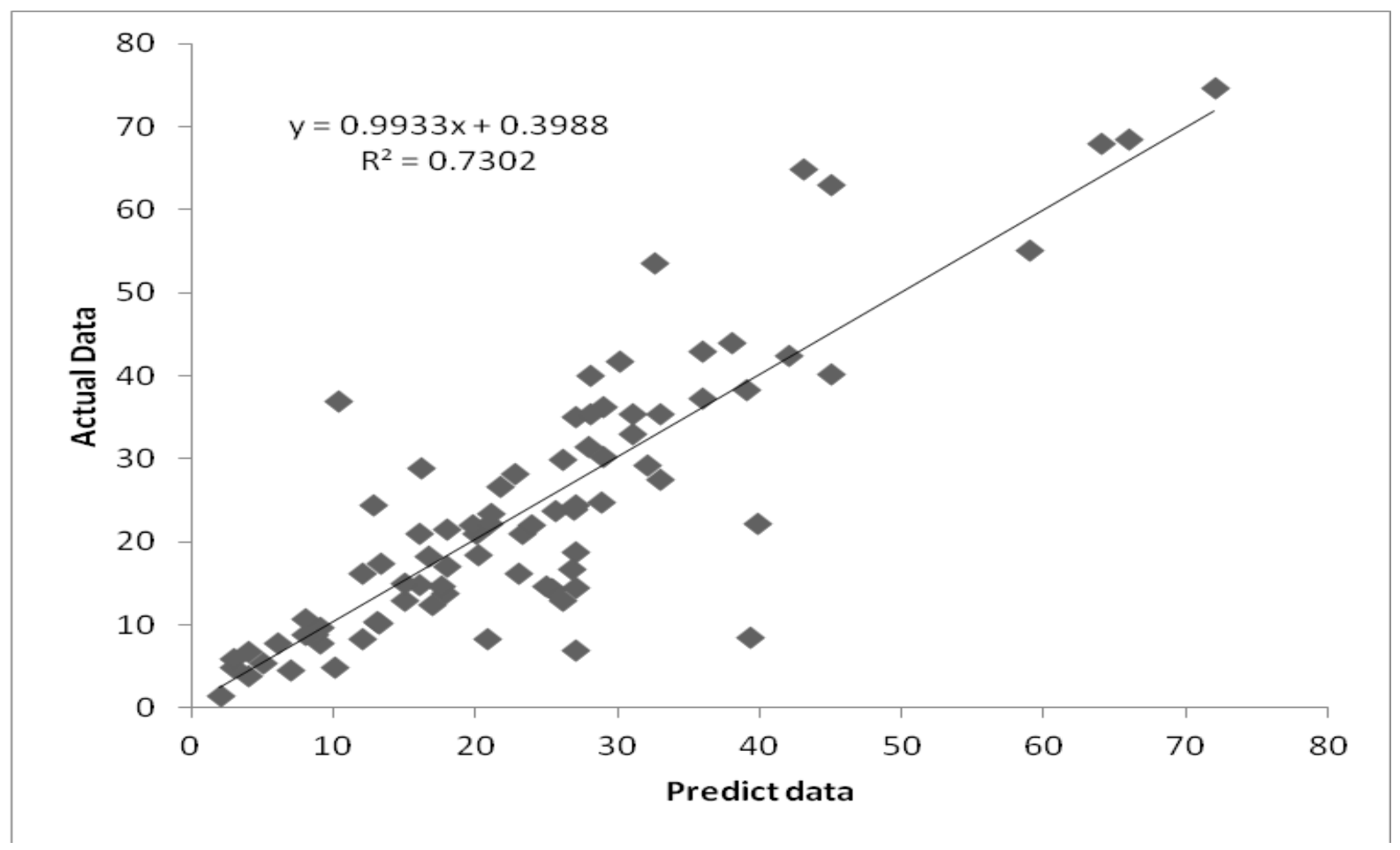

Figure 7: Correlation between results of formula and Experimental data 


\section{Conclusion}

The goal of water-quality zoning is to determine the level of water quality in different zones, identify zones having similar water quality conditions and locating environmentally-critical regions. The GIS maps based on average and maximum concentrations of nitrate in different regions of Iran indicate that the nitrate concentration in samples from some regions were above international and national standards. In some regions, nitrate concentrations had increased in last 10 years. Zoning the nitrate concentrations across Iran by kriging showed a suitable correlation between population density and agricultural water use and drinking water consumption. The GA technique confirms that agricultural activity is the primary source of contamination of groundwater by nitrate in Iran. Agricultural research and education, new eco-biological farms and the reuse of treated wastewater could reduce nitrate groundwater contamination.

Acknowledgement-The authors wish to acknowledge MahdiShahraki (Ph.D. student at SBU) for technical support.

\section{References}

1. Nosrati K., Eeckhaut M., Environ. Earth Sci., 65 (2011) 331.

2. Akhavan S., Abedi-Koupai J., Mousavi S., Afyuni M., Eslamian S., Abbaspour K., Agric. Ecosyst. Environ., 139 (2010) 675.

3. USGS., The USGS Water Science School. United States Geological Survey (2014).

4. El Fehri I. C., El Abidi A., Fekhaoui M., Bellaouchou A., El Jaoudi R., Sabounji A., J. Mater. Environ. Sci., 7 (2016) 1267.

5. $\quad$ Kherad Pisheh Z., Almodaresi S.A., Khaksar Y., Rafati L., Desert, 19(2014) 83.

6. Chitsazan M., Akhtari Y., Water Resour. Res., 23(2008) 1137.

7. Talbot M.R., Last W.M., Smol R., Editors. 2001, Springer Netherlands: Dordrecht.(2001) 401.

8. Jalali M., Environ. Geol., 52(2006) 1133.

9. Menció A., Mas-Pla J., Otero N., Regàs O., Boy-R., Mercè Puig., Roger Bach., Joan D., Cristina Z., Manel B., David F., Sci. Total Environ., 539 (2016) 241

10. Oakley S.M., Gold A.J., Oczkowski A.J., Ecol. Eng., 36(2010)1520.

11. Moreno-Corral R., Tetrahedron, 71 (2015) 1232.

12. Katharina Wick A, Erwin S., J. Environ. Manage., 111(2012) 178.

13. Pardo I., Eulogio-Chica O., Mario Luque E., Juan A., Rodríguez-G., Sci. Total Environ., 532 (2015)162.

14. Standard \#1053 of Iran, National Institute of Standards and Industrial Research of Iran (2009).

15. WHO, Guidelines for Drinking-Water Quality, World Health Organization (WHO) (2011).

16. EPA, U.S. EPA Toxicity and Exposure Assessment for Children's Health, (2006).

17. Bolger. P, Stevens M., Land and Water Resources Research and Development Corporation, (LWRRDC): Australia (1999).

18. Raheli-Namin B, Mobinifar M., Adeli M., J. Mater. Environ. Sci. , 7 (2016) 259.

19. Wang, M. X., Liu, G. D., Wu, W. L., Bao, Y. H., Liu, W. N., Environ. Geol., 50 (2006) 637.

20. Nas B., Berktay A.,J. Environ. Manage., 79 (2006) 30.

21. USGS map on nitrate contamination. Available from:http://water.usgs.gov/edu/nitrogen.html.es/faq figure7.html.

22. Ben Aakame R.,Fekhaoui M., BellaouchouA., El Abidi A.,El Abbassi M., Saoiabi A., J. Mater. Environ. Sci., 6 (2016)1228.

23. EL Maataoui Y., Zouhir A., Laraki L., EL M'Rabet M., Dahchour A., Zrineh A., EL Hajjaji S., Maaroufi A., J. Mater. Environ. Sci.,7 (2016) 2170.

24. Tavakoli M.,Water Resources Management company, ministry of energy of Iran (2012).

25. Eskandari S., Chuvieco E., Int. J. Appl. Earth Obs. Geoinf., 42 (2015) 57.

26. Belfer Center for Science and International Affairs. Maps and Related Resources (Iran) (2010). Available from: http://iranmatters.belfercenter.org/iran101/maps-and-related-resources].

27. Statistical Center of Iran. Statistical Center of Iran. (2016), Available from: http://www.amar.org.ir/.

28. Malakootian M., Karimi A., Faculty of Public Health, Yazd, (2008) 34.

29. Kord I, Asghari Moghadam A., Nakhei M., J. Ecol., 41(2015) 67.

30. Asghari moghadam A., Barzegar R., Journal of Soil and Water[Persian],24(2014) 11.

31. Setare P, Rezaei M., Hasani A., Zinatizade A., J. Kermanshah Univ. Med. Sci., 4(2012).

32. Fakhri M., J. Ecol., 41(2015) 49. 
33. Raghimi M, Mojaveri M., Khademi M., J Gorgan Uni. Med. Sci. [Persian],10 (2007) 34.

34. Karami A., Fekri M., Majd F., Eleventh seminar water and reduce evaporation, (2011), Kerman Iran.

35. Naseri H., Kalantar N., Fifth Geological Conference in Iran, G.S.O. Iran, (2001), Tehran, Iran.

36. Ghafari M, Daneshfaraz S., Fourth Conference on Water Resources Management, ( 2011),Amirkabir University (Polytechnic university of Tehran), Tehran, Iran.

37. Saheli S, Khaledian A., Forghani S., Rezaei M., Second National Conference on Research in Water Resources (2010), Guilan, Iran.

38. Fijani E., Nadiri A., Asghari Moghaddam A., Frank T. C., Dixon B., J. Hydrol., 503 (2013) 89.

39. Moeinial KH., Hosein Nejad A., Rastguo T., J. Guilan Univ. Med. Sci.[Persian], 5 (2011) 26.

40. Amiri H., Zare M., Widory D., Isot. Environ. Health Stud., 51 (2015) 392.

41. Rahini m. The first International Congress of Earth Sciences, (2013), Tehran, Iran.

42. Fallah S, Rasouli F., Journal of agricultural water[Persian], 26 (2011).

43. Farshad A., Imandel K., Journal of School Health[Persian], 33 (2001).

44. Zare M., Haji Ketabi M., National Conference on the water with clean water approach (2011) Tehran, Iran.

45. Mehrabani M., Dehghani M., Talayi A., Jarfi S., Shayegh M., National Conference of Environmental Health Engineering, (2008) Shahid Beheshti University of Medical Sciences,Tehran, Iran.

46. Akhundi M.j., Ghadimi F., Third International Conference on Water Resources Management (2008), Tabriz university, Tabriz, Iran.

47. Samani S., Kalantari N., Rahimi N.,Conservation of soil and water resources[Persian], 1 (2011).

48. Amarlouei A., Nazari M.,Nourmoradi H., J. Ilam Univ. Med. Sci.[Persian], 22 (2014).

49. Rostami zarrin Abadi A., Third Conference on Earth Sciences. (2011), Tehran, Iran.

50. Khosravi dehkordi A., Afuni A., Mousavi M., Journal of Environmental Studies[Persian], 39 (2006) 33.

51. Ahmadi Khalaji A., Rostami Zarinabadi A., Tahmasbi Z., Fazeli Z, Zeinivand A., International Research Journal of Applied and Basic Sciences (IRJABS), 9 (2015) 928.

52. Gheysari M., Houdji M., Najafi P., Abdollahi A., Environmental Earth Sciences[Persian], 33(2007) 35.

53. Mostafavi R., Fazl Avali R., First National Conference on Water Resources Management littoral (2009) Sari, Iran.

54. Jafari malekabadi A., Mousavi M., Afyouni F., Khosravi S., Journal of Technology of Agriculture and Natural Resources[Persian], 1 (2003) 8.

55. Forughi R., Water Environment Technology, (2012) 292.

56. Shahbazi F., Esmaeili A.,World Appl. Sci. J., 5 (2009) 92.

57. Amin M. M., Ebrahimi A., Hajian M., J. Environ. Health. Sci. Eng, 7 (2010) 71.

58. Esmaili R., Hoseinzade M., Akbari M., J. Tethys, 4 (2013) 254.

59. Rahmani H., Koushafar M., Reaserch journal of environmental toxicology (RJET), 2 (2007)92.

60. Esfandyari Y., Tilaki D., Ali R, Kariminejad F., J. Mazandaran Univ. Med. Sci.,130 (2015) 159.

61. Mozafarizade J., Sajadi Z., The first national conference on the environment, (2014), Dehaghan, Iran.

62. Nourozi H., Second National Conference on Environmental Health, (2007), Hamedan, Iran.

63. Joekar-Niasar V., Ataie-Ashtiani B., Environ. Geol.,57 (2009) 1785.

64. Shirani Z., Journal of humans and the environment[Persian], 24 (2013).

65. Jahed Khaniki G., Dehghani M., Mahvi A., Rafati L., Tavanfar F., Res. J. Chem. Environ., 12 (2008).

66. Jalali M., Environ. Monit. Assess.,130 (2006) 347.

67. Imani A., Nezami M., Lotrollahi M., Tavasoli A., Conference and Exhibition of Environmental Engineering, (2009), Tehran, Iran.

68. Kord I., Zamanian S., Ranjbar N., Safdardoust., Conference on water pollution and its treatment, (2003), medical university of Tehran, Tehran, Iran.

69. Tabaei S., J. Ecol.,53(2010) 55.

70. Abbaspour K., Iran Water Research[Persian], 4(2009) 9.

71. Jalali M., Environ. Geol., 51 (2006) 433.

72. Ostovari Y., Water management and irrigation[Persian], 1(2011) 55.

73. Jalali M., Environ. Geol., 7 (2008) 1479.

74. Dördelmann O., Panglisch S., Klegraf F., Hell F., Moshiri A., Emami A., Höll W. H., IWA congress. (2008), Wien.

75. Latif M., Musavi F., Afuni M., Velayati S., Journal of Agricultural Sciences and Natural Resources [Persian], 6 (2001). 
76. Zaboli zade P., Mazlumi.P., Moghadas A.R., Ghezi A., First national conference on environmental pollution With a focus on clean land, (2013), Ardebil, Iran.

77. Amouei A., Mahvi A., Mohammadi A., Horieh Fallah S., Asgharian H., Khafajeh A., World Appl. Sci. J., 18 (2012) 693.

78. Sadeghi mehr S., Maleki S., Afruzi M., National conference of water crisis in Iran, (2013), Shiraz, Iran.

79. Hosseinpour M., Lashkaripour G., Dehghan P., International Journal of Plant, Animal and Environmental Sciences (IJPAES), 2 (2014) 301.

80. Dashti Barmaki M., Rezaei M., Saberi Nasr A. , Geol. Eng.,2 (2014) 2121.

81. Naseri H., Alijani F., Environ. Sci., 4(2008).

82. Ebrahimi A., Journal of Health System Research [Persian], 6 (2009) 1048.

83. Kalantari N., Rahimi M., Matoori F., J. Ecol., 56 (2010) 39.

84. Bazrafshan E., Fourth International Congress of Geographers and the Islamic world (ICIWG 2010), (2010).

85. Ghadimi M., Esmaeili A., National Conference \& Exhibition on Environmental Engineering, (2010), Tehran, Iran.

86. Soori M., Biglari H., Onagh K., Seydi SH., First Nantional Conference on Management amd New Technology in Sanitary and Environment, ( 2003), Tehran, Iran.

87. Fallah H., J. Guilan Uni. Med. Sci. [Persian], 15 (2011) 1.

88. Fakhri Y., Rasuli L., Rafieepour A., Langarizadeh Gh., Moradi B., Zandsalimi Y.,Jafarzadeh S.,Mirzaei M.,IOSR Journal of Environmental Science, Toxicology and Food Technology (IOSR-JESTFT), 4 (2015) 2319.

89. Ehenzi Z., Nazari M., Conference on Environmental Research, (2013), Hamedan,Iran.

90. Jamshidi M., Rahimi A., Mansoori N., Naderi G., World Journal of Fish and Marine Sciences (WJFMS), 1 (2012) 11.

91. Kazemi G., Hydrogeol. J., 12 (2004) 723.

92. Dindarlou K., Alipour V., Fargher F., J. Hormozgan Uni. Med. Sci. [Persian], 85( 2014) 57.

93. Kholghi M., Taki R., Eng. Geol.,3(2002).

94. Pasban A., J.North Khorasan Uni. Med. Sci. [Persian], 2 (2008).

95. Shokri H., International Congress of Earth Sciences, (2013), Tehran, Iran.

96. Hoseyni M., Zareei V., $6^{\text {th }}$ National Conference \& Exhibition on Environmental Engineering. (2012), Tehran, Iran.

97. Moasheri S. A., Tabatabaei S., International Conference on Transport, Environment and Civil Engineering (ICTECE'2012),(2012), Kuala Lumpur,Malaysia.

98. Dehghani M., Abbasnezhad A., Environmental Earth Sciences [Persian], 56 (2009) 87.

99. Habibi Davijani M., Nadjafzadeh Anvar A., Banihabib M.E., Water Resour. Manage., 28 (2014) 3341.

100. Vatankhah M., Izanluo H., Maleki A., Soil Tillage Res., 43 (2013) 203.

(2017) ; http://www.jmaterenvironsci.com/ 